\title{
ANALISIS HUKUM EKONOMI ISLAM
}

\section{TERHADAP PRAKTEK IHTIKAR}

\author{
Fasiha \\ Fakultas Ekonomi dan Bisnis Islam, Institut Agama Islam Negeri (IAIN) Palopo \\ fasiha@iainpalopo.ac.id \\ Muh. Ruslan Abdullah \\ Fakultas Syariah, Institut Agama Islam Negeri (IAIN) Palopo \\ muh_ruslan_abdullah@iainpalopo.ac.id
}

\begin{abstract}
The purpose of this paper is to explain the Ihtikar law in trade and commercial activities. Islam emphasizes the implementation of moral values in all economic activities, so the ihtikar issue is very important to be studied in Islamic economic law. Islam basically gives freedom in carrying out economic activities, and Islam also regulates economic matters that cause harm. The results of the study found that the verses and hadith explained in this paper textually prohibit the existence of ihtikar. Ihtikar law is haram if the goods stockpiled are needed by the community which results in price increases. When this happens, Islam allows for intervention in economic activity by issuing some policies and rules that have an impact on normal prices.
\end{abstract}

Keywords : Ihtikar Law, Trading, Islamic Economic Law

\begin{abstract}
Abstrak
Tujuan tulisan ini bertujuan untuk menjelaskan Hukum Ihtikar dalam aktivitas perdagangan dan perniagaan. Islam menekankan adanya implementasi nilai-nilai moral dalam segala aktivitas ekonomi, sehingga persoalan Ihtikar sangat penting untuk dikaji dalam Hukum Ekonomi Islam. Islam pada dasarnya memberikan kebebasan dalam melakukan aktivitas ekonomi, dan Islam juga mengatur perkara ekonomi yang menimbulkan mudharat. Hasil kajian menemukan bahwa ayat dan hadist yang diangkat dalam tulisan ini secara tekstual telah melarang adanya ihtikar. Hukum Ihtikar adalah haram jika barang yang ditimbun sangat dibutuhkan masyarakat yang berakibat terjadinya kenaikan harga. Ketika hal demikian terjadi, Islam membolehkan adanya intervensi terhadap aktivitas ekonomi tersebut dengan mengeluarkan beberapa kebijkan dan aturan yang berdampak pada harga yang normal.
\end{abstract}

Kata Kunci : Hukum Ihtikar, Perdagangan, Hukum Ekonomi Islam

\section{PENDAHULUAN}

Keuntungan sebagai motif bisnis, para pelaku usaha menghalalkan apa pun untuk memperoleh keuntungan, sehingga terjadi persaingan tidak sehat. Pasar domestik sarat dengan praktek monopoli yang berdampak buruknya mekanisme 
pasar. Pertumbuhan ekonomi bagi Negara berkembangan sangat ditentukan oleh kondisi bisnis yang kondusif bagi pengusaha. (Wie, 1999).

Studi tentang struktur pasar menjadi sangat penting dibahas dalam Hukum Ekonomi Islam, disebabkan penentuan harga dalam konsep Hukum Ekonomi Islam didasarkan pada hukum kekuatan pasar yaitu hukum permintaan dan hukum penawaran. Rasulullah SAW mengeluarkan kebijakan terkait dengan pengaturan harga yaitu menyerahkan kepada pasar untuk membentuk harga karena menurutnya hanga pasar adalah harga yang adil. Kemudian Rasulullah tidak melakukan intervensi harga jika harga tersebut dibentuk oleh mekanisme pasar yang baik, sebaliknya Islam mengharuskan adanya intervensi jika harga tidak dibentuk oleh mekanisme pasar yang tidak wajar. Perubahan harga disebabkan oleh pertama; usaha spekulatif, Kedua; penimbunan, Ketiga; perdagangan gelap dan penyelundupan. Kecenderungan untuk menimbun dan melakukan transaksi pasar gelap akan berdampak pada ketidakstabilan harga dipasar. (Mannan, 1997). Perdagangan akan mengalami iklim kondusif apabila terdapat keamanan dan ketentraman dalam aktivitas ekonomi. (Al-Haritsi, 2006). Pemerintah tidak memiliki hak untuk mengatur harga suatu komoditas, sisi lain di Indonesia telah terdapat Undang-Undang terkait dengan larangan praktek monopoli. Dalam konsep Islam pemerintah memiliki hak dan dipandang wajib menetapkan harga atau intervensi pasar jika kenaikan harga disebabkan oleh distorsi pasar (Malaka, 2014). Praktik monopoli berdampak pada terganggunya mekanisme pasar, sehingga monopoli dikategorikan sebagai praktek yang dilarang dalam aktivitas muamalah. Pelarang tersebut didasarkan pada adanya kerugian yang dialami oleh konsumen disatu sisi produsen mengalami keuntungan yang maksimal. (Fatah, 2012) dan ihtikar berpengaruh negatif terhadap tersedianya barang dan permintaan tidak stabil sehingga muncul distorsi pasar (Saragih, 2017)

Pasar yang idel ketika tidak terjadi distorsi pasar (market distortion) yang dapat berdampak pada ketidakseimbangan pasar, sehingga dibutuhkan kebijakan pemerintah yang dapat menciptakan keseimbangan pasar (Hakim, 2017). Distorsi pasar dalam Ekonomi Islam dibedakan menjadi tiga jenis, yaitu; 1) distorsi yang terjadi pada penawaran dan permintaan, 2) distorsi yang disebabkan adanya tadlis, 
dan 3) distorsi yang disebabkan adanya ketidakpastian (taghrir). Tulisan ini akan mengkaji hokum terkait dengan distorsi pasar yang diakibatkan oleh permintaan dan penawaran dalam termologi Islam disebut Ihtikar. Sebagai agama yang komprehensif tentunya membahas secara detail terkait aktivitas ekonomi sebagai kegiatan vital kemanusiaan tidak luput dari perhatian. "Allah telah menghalalkan jual beli dan mengharamkan riba" (QS Al-Baqarah [2]: 275), Ayat-ayat inilah yang menunjukkan sebagian dari sekian banyak ayat Al-Qur'an yang merujuk pada aktivitas ekonomi. Fokus tulisan ini adalah praktek monopoli yang dikaitkan dengan praktek Ihtikar atau secara popular disebut sebagai menimbun. Ihtikar secara etismologi berarti menahan makanan agar harganya mahal. Perubahan seperti ini disebut al-hukrah. (Ath-Thayyar, 2009). Dan tujuan tulisan ini adalah untuk mengkaji praktek menimbun dengan pendekatan hukum Ekonomi Islam. Tulisan ini disandarkan pada literatur yang terkait dengan tema atau menggunakan metode kepustakaan yaitu menelusuri literatur terkait dengan Ihtikar.

\section{PRAKTEK IHTIKAR}

Adapun Ihtikar secara terminologi adalah jika sesorang membeli makanan pada saat harga mahal, kemudian ia menimbunnya untuk dijual dengan harga lebih mahal ketika kebutuhan terhadap makanan tersebut mendesak (Ath-Thayyar, 2009) Menimbun dalam bahasa Arab adalah ihtikar dari kata ihtikara-yahtakiru yang bermakna secara bahasa adalah alhabsu (menahan) dan aljam'u (mengumpulkan) secara etimologi ialah perbuatan menimbun, pengumpulan (barang-barang) atau tempat untuk menimbun (Poerwadarminta, 1976). Ibnu Mandhur berkata: "Yaitu menahan (tidak menjual) bahan makanan sambil menunggu kenaikan harga” (rahimahulloh, Tahdzib al-Asma' wa al-Lughoh, t.th). Makna Ihtakar secara lugawi adalah menumpukkan barang secara mutlak. sehingga Ihtakar tidak hanya terbatas menimbung makanan pokok, atau sesuatu kebutuhan pokok, melainkan semuanya yang terkait dengan penimbunan sesuatu barang yang sangat dibutuhkan oleh manusia, karena hadist-hadist yang ada menyatakan dengan mutlak, tanpa disertai batasan apa pun, serta umum tanpa disertai takhshis apa pun, sehingga, kemutlakan dan keumumannya tetap berlaku (An-Nabhani, 2002). Sedangkan makna secara syar'i al-ihtikar adalah 
menghentikan distribusi barang ke pasar, disisi lain yang melakukan tersebut bukan karena alasan kebutuhannya, melaikan alasan karena profit yaitu menjualnya di saat harga melambung tinggi. Adapun menimbun secara terminologis adalah menahan barang yang diperjual belikan untuk berharap keuntungan yang banyak (Qasim, 1986). Yusuf Qardhawi mengartikan monopoli adalah menahan barang untuk tidak beredar di pasar dan berharap kemudia harga mengalami kenaikan ( Qardhawi, 1997).

Ihtikar yang terjadi dipasar dapat dikenali dengan melihat bentuknya, yaitu: (a) Natural Monopoly, yaitu Ihtikar terjadi secara alami, (b) Monopoly by Struggle, yaitu ihtikar disebabkan adanya adanya persaingan pasar yang tidak sempurna, dan (c) Monopoly by decree, yaitu proses ihtikar yang disebabkan karena adanya kebijakan pemerintah (Iswardono, 1990). Ihtikar dan monopoli memiliki kesamaan yaitu secara bersama-sama membentuk harga dipasar secara tidak alami dan memiliki motif keuntungan. Pelaku monopoli dan al-ihtikar samasama memiliki hak opsi untuk menawarkan barang-barang ke pasaran atau tidak. Monopoli dan Ihtikar dapat mengakibatkan polemik dan ketidakpuasan pada masyarakat. Monopoli dan Ihtikar merupakan salah satu cara golongan orang kaya untuk mengeksploitasi golongan miskin.

Defenisi tersebut mengarahkan kepada pemahaman bahwa monopoli dan Ihtikar adalah sama, akan tetapi pada dasarnya keduanya memiliki perbedaan sebagai berikut:

Tabel I

Perbedaan Monopoli dan Ihtikar

\begin{tabular}{|l|l|l|l|}
\hline \multicolumn{5}{|c|}{ Perbedaan } \\
\hline No & \multicolumn{1}{|c|}{ Monopoli } & \multicolumn{1}{c|}{ Ihtikar } \\
\hline 1 & $\begin{array}{l}\text { Praktek monopoli dilakukan oleh } \\
\text { pemilik modal, yang modalnya besar } \\
\text { dan memproduksi barang yang } \\
\text { dibutuhkan oleh masyarakat. }\end{array}$ & $\begin{array}{l}\text { Praktek } \\
\text { pemilik } \\
\text { modalnya relative kecil. } \\
\text { modal, walupun }\end{array}$ \\
\hline 2 & $\begin{array}{l}\text { Pelaku usaha yang melakukan } \\
\text { monopoli mengikuti regulasi yang } \\
\text { ditentukan oleh pemerintah. }\end{array}$ & $\begin{array}{l}\text { Praktek ihtikar cenderung } \\
\text { aksidental, artinya praktek } \\
\text { tersebut dilakukan oleh siapa saja } \\
\text { dan kapan pun. }\end{array}$ \\
\hline
\end{tabular}




\begin{tabular}{|l|l|l|}
\hline & \multicolumn{1}{|c|}{} & \\
\hline 3 & $\begin{array}{l}\text { Monopoli dipengaruhi oleh biaya } \\
\text { produksi, opersional yang mahal }\end{array}$ & $\begin{array}{l}\text { Ihtikar mengakibatkan } \\
\text { kelangkaan barang dan berakibat } \\
\text { inflasi }\end{array}$ \\
\hline 4 & Monopoli memiliki status hukum. & $\begin{array}{l}\text { Ihtikar tidak memiliki legatimasi } \\
\text { hukum }\end{array}$ \\
\hline
\end{tabular}

\section{DASAR HUKUM IHTIKAR}

Adapun ayat yang dapat menjelaskan persolan tersebut yaitu: QS. AlTaubah ayat 34-35:

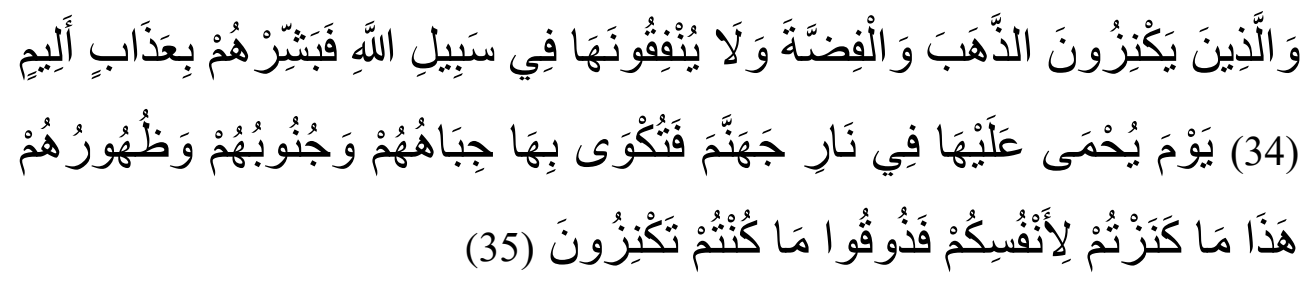

Terjemahan,-

"Dan orang-orang menyimpan emas dan perak dan tidak menafkahkannya pada jalan Allah maka beritahukanlah kepada mereka (bahwa mereka akan mendapat) siksa yang pedih. Pada hari dipanaskan emas perak itu dalam neraka jahannam, lalu dibakar dengannya dahi mereka, lambung, dan punggung mereka (lalu dikatakan kepada mereka): "Inilah harta bendamu yang kamu simpan untuk dirimu sendiri, maka rasakanlah sekarang (akibat dari) apa yang kamu simpan itu”.

Asbabul Nuzul ayat ini adalah diriwayatkan dari Ibnu Abbas bahwa permulaan ayat ini turun berkenan dengan para pendeta dari golongan ahli Kitab yang menganbil suap dari pengikutnya. Penghujung ayat ini turun berkenan dengan ahli kitab dan kaum muslim yang sering menimbun harta benda. Intisari dari ayat ini adalah kebiasaan dari orang-orang yahudi, baik para ulama maupun rahib mereka, melakukan kebatilan, yaitu mencari harta benda dengan cara yang tidak selayaknya dan menghalang-halangi orang-orang yang akan beriman ataupun orang-orang yang telah beriman untuk beribadah kepada Allah. Baik 
dengan ancaman, hukuman yang mereka ada-adakan, maupun menebar rasa takut. Mereka juga selalu menyimpan emas, perak, dan sejenisnya dan enggan untuk menafkahkan dari sebagian harta itu dijalan Allah. Maka dari itu, tidak sepantasnya orang-orang beriman mengikuti apa yang telah meraka lakukan. Jika mereka berlaku demikian, niscaya sama halnya dengan orang-orang Yahudi itu. Jika demikian, kelak pada hari akhir mereka akan memasukkan ke dalam neraka. Mereka akan disiksa dengan siksaan yang pedih (Departemen Agama RI, 2009). Adapun hadis HR. Muslim No. 3012 Kitab Buyu' Bab al-Masaqah yang menjelaskan tentang ihtikar sebagai berikut:

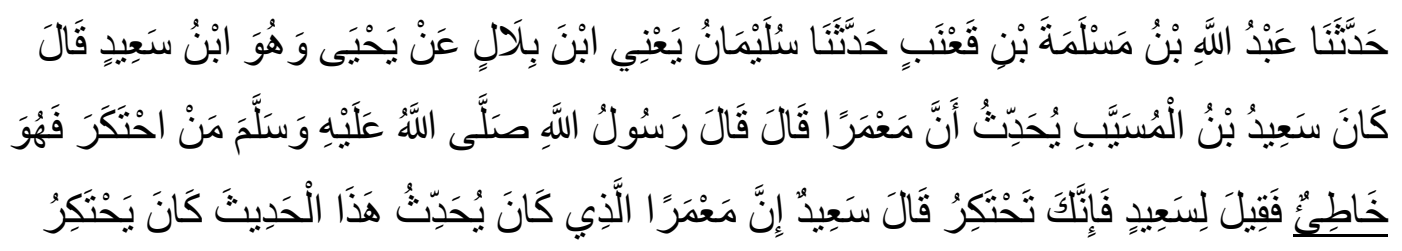

Dalam hadis tersebut Rasulullah bersabda (من احتكر فهو خاطى) barang siapa menimbun maka dia berdosa, pada riwayat lain (لا يحتكر إلاخطاطئ) tidak akan menimbun kecuali orang berdosa. Ahli bahasa berkata لخاطئ artinya orang yang bermaksiat dan berdosa.

\section{IHTIKAR DALAM ANALISIS HUKUM EKONOMI ISLAM}

Perubahan naik turunnya harga barang di pasar sangat dipengaruhi oleh genuin supply dan demand. Lebih khusus, Mannan (1997) menganalisis empat faktor penyebab naiknya harga, yaitu: Bertambahnya persediaan uang, Berkurangnya produktivitas, Bertambahnya kemajuan aktivitas, Berbagai pertimbangan fiskal dan moneter. Ihtikar merupakan faktor yang mengakibatkan harga barang di pasar akan tinggi, karena motif transaksi hanya disandarkan pada memaksimalkan profit (Muhamad, 2004). Qardhawi (1997) menjelaskan bahwa Islam menginginkan harga pasar disebabkan adanya persaingan sempurna (harga keseimbangan).

Para ulama berselisi pendapat terkait obyek Ihtikar: 1) Imam al-Gazali (ahli fiqh mazhab asy-Syafi'i) berpendapat Ihtikar hanya dibatasi jenis barang pokok, 2) Imam Abu Yusuf (ahli fikih mazhab Hanafi) berpendapat Ihtikar tidak dibatasi 
oleh barang pokok akan tetapi setiap barang yang dibutuhkan. Menurut mereka, yang menjadi motivasi hukum dalam larangan melakukan ihtikar tersebut adalah kemudharalatan yang menimpa orang banyak ( Dahlan , 1996). As-Sayyid Sabiq, (1981) dalam Fiqh as-Sunnah menjelaskan bahwa proses terjadinya ihtikar dengan cara membeli barang kemudian menimbung, sehingga terjadi kelangkaan di pasar yang mengakibatkan masyarakat sulit memperoleh barang yang dibutuhkan kecuali dengan membanyar lebih tinggi dari harga normal. Adiwarman Karim juga menjelaskan Ihtikar adalah memperoleh keuntungan dari menjual dengan harga tinggi yang diawali dengan adanya praktek menyimpang seperti menimbung (Karim, 2000).

Meskipun demikian, tetap memberikan pengecualian untuk beberapa jenis industri seperti perikanan, pertanian, ekspor-impor, IT, tranfortasi lembaga keuangan, dan telekomunikasi. Praktek tersebut diperbolrhkan dalam ekonomi konvensional yang dikenal dengan istilah natural monopoly. Praktek monopoli tersebut dapat dilihat dari beberapa perusahaan seperti PLTA dan PERTAMINA (Karim, 2001).

Para ahli fiqhi berpendapat, bahwa yang dimaksud dengan menimbun terlarang adalah yang terdapat syarat sebagai berikut (Sabiq S. , 1990):

a. Kelebihan dari kebutuhannya yang ditimbun

b. Menyimpan atau menahan barang sampai dipasar dengan harapan harga akan naik, dengan begitu menjadi keuntungan bagi mereka.

c.Menyimpan atau menahan barang pada saat barang langkah yang berakibat sulitnya manusia memenuhi kebutuhan.

Para ulama berselisih pendapat terkait status hukum Ihtikar, dengan perincian sebagai berikut:

a. Haramnya Ihtikar karena ada hadist yang berbunyi, Barangsiapa yang melakukan ihtikar maka hukumnya adalah dosa. (HR. Muslim Kitab alBuyu' bab Tahrim al-Ihtikar fil Aqwat 1605)

b. Makruhnya Ihtikar karena hanya terbatas kepada hukum makruh saja karena hadist larangan Ihtikar hanya sebagai pengingat atau peringatan. 
c. Haramnya ihtikar karena menyangkut bahan pokok seperti makanan pokok, tapi selain bahan pokok maka dibolehkan sebagaimana hadis yang diriwayatkan oleh Muslim dalam kitab al-Buyu' bab Tahrim alIhtikar fil Aqwat 1605.

d. Haramnya Ihtikar jika mempengaruhi perekonomian disuatu daerah diantaranya naiknya harga suatu komuditi

e. Bolehnya Ihtikar jika praktek tersebut hanya sifatnya sementara tanpa tujuan memperoleh keuntungan, seperti hanya menyimpan digudang sebagai proses aktivitas distribusi barang (HR. Bukhori 2131, dan Muslim $5 / 8)$.

Para ulama juga berselisih paham terkait dengan barang yang haram ditimbun, ada dua pendapat yang terkenal dalam hal tersebut;

a. Imam Hanafi, Sufyan ats-Tsauri, dan Imam Malik berpendapat bahwa hanya barang yang sangat dibutuhkan oleh manusia karena larangan Ihtikar bersifat umum

b. Imam Syafi'i dan Imam Ahmad mengutarakan bahwa Ihtikar yang diharamkan adalah bahan makanan pokok saja, dengan dalil beberapa riwayat yang muqoyyad (yang disebutkan secara khusus bahan makanan), dikuatkan dengan apa yang dilakukan Rosululloh Shallollohu 'alaihi wa sallam, beliau pernah menyimpan bahan makanan keluarganya untuk satu tahun penuh (HR. Bukhori 5357, dan Muslim 1757), pada masa rasulullah ada beberapa sahabat yang melakukan penimbunan seperti ma'mar yang menimbun minyak.

Dari beberapa pendapat di atas terdapat pendapat yang kuat yaitu pendapat yang menyatakan bahwa penimbunan barang yang sangat dibutuhkan masyarakat dikategorikan haram dan dilarang, hal ini disebabkan adanya perkara;

a. Hadis Rasulullah Shallalahu 'alaihi wa sallam tentang larangan menimbun tidak mengkhusukan bahan makanan saja, sebagai sabda beliau; Barangsiapa menimbun maka dia berbuat dosa. (HR. Muslim Kitab al-Buyu' bab Tahrim al-Ihtikar fil Aqwat 1605). Dalil-dalil larangan menimbun/ihtikar bersifat umum, adapun beberapa hadist yang 
menyebutkan khusus bahan makanan, maka itu termasuk penyebutan contoh barang yang dilarang, bukan untuk mengkhususkan, berkata Imam Syaukani rahimahulloh "Penyebutan lafadz tha'amu (bahan makanan) dalam beberapa riwayat yang lain tidak sah dijadikan sebagai pengikat (dari lafadz yang mutlak), akan tetapi disebutkan "bahan makanan" adalah bermaksud sebagai salah satu contoh dari sekian banyak contohcontoh barang yang dilarang untuk ditimbun secara mutlak....." (Nailul Author 3/604)

b. Adapun yang disebutkan dalam hadist bahwa Ma'mar radhiallohu 'anhu pernah menimbun minyak, maka jawabannya.

1) Sebagaimana dikatakan oleh Ibnu Abdil Bar dan lainnya, bahwa beliau menimbun minyak, karena beliau mengetahui bahwa larangan ihtikar adalah ketika manusia sedang sangat membutuhkannya, (sedangkan saat itu kondisi manusia tidak sangat membutuhkan)

2) Beliau menyimpan minyak bukan untuk menjualnya dengan harga yang tinggi, tetapi untuk keperluan rumah tangganya, sehingga hal ini sama dengan yang dilakukan Nabi Shallallahu 'alaihi wa sallam ketika menyimpan bahan makanan keluarganya untuk satu tahun penuh, dan ini bukan termasuk ihtikar yang terlarang.

c. Adapun perkataan mereka bahwa Rasululloh Shallollohu 'alaihi wa sallam pernah melakukan ihtikar dengan menyimpan bahan makanan selama setahun penuh untuk keluarganya, maka jawabnya antara lain;

1) Sebagaimana yang dikatakan oleh al-Hafidz, beliau mengatakan: "Bisa saja (Imam Bukhori yang membolehkan ihtikar) lantaran menurutnya hadits Ma'mar yang dikeluarkan Imam Muslim adalah tidak sah" (Fathul Bari 4/40)

2) Al-Hafidz juga mengatakan, "bahwa sekedar menyimpan barang di rumah bukan berarti menimbun/Ihtikar yang dilarang, karena Ihtikar yang dilarang adalah menahan bahan makanan (tidak menjualnya), padahal dia tidak membutuhkannya, sedangkan manusia sangat 
membutuhkannya, lalu menjualnya disaat harga melambung tinggi”, (Fathul Bari 4/40)

3) Hal ini menunjukkan bahwa Ihtikar yang dilarang adalah dengan syarat yang disebutkan di atas, adapun sekedar menyimpan bahan kebutuhan manusia seperti yang dilakukan Nabi Shallollohu 'alaihi wa sallam, maka bukan termasuk Ihtikar yang dilarang.

Adapun pendapat yang mengatakan hokum Ihtikar adalah makruh, maka terbantah dengan nash hadist yang menyebutkan bahwa: "Bahwa barangsiapa yang menimbun maka dia telah berbuat dosa." (HR. Muslim 1605), hal ini lantaran tidak akan dikatakan berbuat dosa kecuali orang yang melakukan hal yang diharamkan oleh Allah Subhanahu wa Ta'ala dan Rasul-Nya. Praktek monopoli telah diatur dalam Undang-Undang Republik Indonesia Nomor 5 Tahun 1999 Tentang Larangan Praktek Monopoli dan Persaingan Usaha Tidak Sehat. Dalam Undang- Undang tersebut mengatur tentang larangan pengaturan harga secara tidak rasional atau mempermaikan harga. Pemerintah ebelumnya juga telah mengatur tentang penimbunan barang-barang yang mengakibatkan melonjaknya harga dipasar. Dengan adanya dua aturan tersebut telah memberikan status hukum penimbunan adalah dilarang dan dikategorikan melanggar aturan yang telah ditetapkan oleh Negara. Aturan tersebut mengikat dan berakibat adanya sanksi bagi pelaku usaha yang melakukan monopoli dan penimbunan.

\section{PENUTUP}

Al-Ihtikar adalah Menahan suatu barang untuk tidak diperjual belikan sampai harga barang pada titik tertinggi ketika harga suatu barang sudah naik barulah diperjual belikan. Kondisi tersebut dapat mengakibatkan polemik perubahan harga yang tidak wajar yang cenderung naik. Perubahan naik turunnya harga barang di pasar juga sangat dipengaruhi oleh genuine supply dan demand. Mannan menganalisis empat faktor penyebab naiknya harga dan Ihtikar merupakan salah satu faktor yang mengakibatkan harga barang di pasar akan tinggi, disisi lain Islam menginginkan harga pasar yang muncul dari persaingan sempurna. Para ahli fiqhi dan ulama pada dasarnya sepakat terkait dengan 
pengharaman terkait peraktek Ihtikar karena menyebabkan tidak normalnya harga pasar. Perbedaan pendapat hanya terkait dengan objek dan motif Ihtikar. Pengharaman Ihtikar ketika objek atau barang yang diperdagangkan adalah barang yang sangat dibutuhkan oleh masyarkat seperti bahan pokok, BBM dan barang jenis lainnya yang ketika ditimbun akan mengakibatkan terjadinya loncatan harga pasar. Ihtikar dibolehkan ketika pemimbunan barang dilakukan dengan tujuan pemenuhan kebutuhan sehari-hari.

\section{DAFTAR PUSTAKA}

Dahlan, A. A. (1996). Ensiklopedi Hukum Islam. Jakarta: PT. Ikhtiar Baru.

Fatah, D. A. (2012). Monopoli dalam Perpektif Ekonomi Islam. Al-Iqtishad, 4(2), 159.

Qardhawi, Y. (1997). Peran Nilai dan Moral Dalam Perekonomian Islam. Jakarta: Robbani Press.

Al-Haritsi, J. b. (2006). Fikih Ekonomi Umar bin Khathab. Jakarta: Khalifah.

An-Nabhani, T. (2002). An-Nidlam Al-Iqtishadi Fil Islam, Membangun sistem ekonomi alternatif; perpektif Islam. Surabya: Risala Gusti.

Ath-Thayyar, A. b. (2009). Abdullah bin Muhammad Ath-Thayyar dkk, Ensiklopedi Fiqhi Muamalah dalam pandangan 4 Madzhab (; Maktabah Al-Hanif, 2009), h. 71. Yogyakarta: Maktabah Al-Hanif.

Hakim, L. (2017). Distorsi Pasar dalam Pandangan Ekonomi Islam. Ekomadania, l(1), 1 .

Iswardono. (1990). Ekonomi Mikro. Yogyakarta: UPP AMP YKPN.

Karim , A. (2001). Ekonomi Islam Suatu Kajian Kontemporer (Cet. I ed.). Jakarta: Gema Insani Press.

Karim, A. (2000). Ekonomi Mikro Islam. Jakarta: IIIT Indonesia.

Malaka, M. (2014). Praktek Monopoli dan Persaingan Usaha. Jurnal Al-Adl, 7(2), 39.

Mannan, M. A. (1997). Teori dan Praktek Ekonomi Islam . Yogyakarta: PT. Dana Bhakti Prima Yasa.

Muhamad. (2004). Ekonomi Mikro Dalam Perspektif Islam (Cet. I ed.). Yogyakarta: BPFE. 
Poerwadarminta, W. (1976). Kamus Umum Bahasa Indonesia. Jakarta: Balai Pustaka.

Qasim, Y. (1986). At-Ta'mil at-Tijariyyi fi Mijan asy-Syari'ah. Kairo: Dar anNahdhoh al-'Arabiyyah.

Rahimahulloh, N. (t.th). Tahdzib al-Asma' wa al-Lughoh. t.tp: t.p.

Departemen Agama RI (2009). Syamil Al-Qur'an The Miracle 15 in 1 . Bandung: PT. Sygma Examedia Arkanleema.

Sabiq, A.-S. (1981). Fiqh as-Sunnah. Libanon: Dar al-Fikr.

Sabiq, S. (1990). Fikhi Sunnah no. 12. Kuala Lumpur: Victory Agencie.

Saragih, E. J. (2017). Konsep Monopoli dalam Islam. Al-Maslahah - Volume 13 Nomor 2 Oktober 2017, 13(2), 267.

Wie, T. K. (1999). Hukum Persaingan: Aspek-aspek Ekonomi yang Per!u Diperhatikan dalam Implementasi UU No. 5/1999. Jurnal Hukun Bisnis, 60 . 